\title{
The Effects of Aqueous Leaf Extract of Gmelina Arborea on the Haematological and Biochemical Profile of Aibino Rats.
}

\author{
Oguwike F. N And Offor C. C \\ Department of Human Physiology Anambra State University, Uli Anambra State.
}

\begin{abstract}
The haematological and biochemical response of albino rats to their administration with the aqueous extracts of Gmelina arborea was studied. Fifty-six (56) female albino rats within the weight range of 140-160g were used. They were placed into 3 groups $(A, B, C)$. They were fed with high dose (Group A), low dose (Group $B$ ) and extract free (Group C) for 28 days.

Haematological tests were performed with blood samples collected from the animals. Result showed that Gmelina aborea increases Haemoglobin concentration, Packed Cell Volume, platelet count while the white blood cell count, and white blood cell differential count were unaffected compared with their corresponding control. There was no marked difference in the liver function test of the test and control rats. It could be deduced from this study that the extract of Gmelina aborea encourages haemopoiesis in rats.

Key Words: Gmelina aborea, albino rats white blood cells, platelets.
\end{abstract}

\section{Introduction}

Gmelina arborea locally known as Gamhar is a fast growing deciduous tree (Jensen 1995) occurring naturally throughout greater part of India, Vietnam, Nigeria, Sierra Leone, Malaysia, China, Laos and Thailand. It is also planted in gardens and avenues. English people calls it Beechwood.

Gmelina arborea grows on different localities and prefers moist fertile valleys with $750-4500 \mathrm{~mm}$ rainfall. It does not thrive on ill-drained soils, drought also reduces it to a shrubby form. The leaf is green and the fruit is up to $2.5 \mathrm{~cm}$ long, smooth, dark green, turning yellow when ripe, has a fruity smell and seed inside.

Gmelina arborea timber is reasonably strong for its weight. It is used in constructions, furniture, carriages, sports, musical instruments, cupboards, lightweight, stability and durability.

The wood is also used for manufacturing tea chest and general purpose plywood, blackboards, frame core and cross bands of flush door shutters.

The yellow or brown flowers are arranged in pinnacled cymes $15-30 \mathrm{~cm}$ long, which appear after leaf-fall. The trumpet shaped flowers are $4 \mathrm{~cm}$ long and are hairy and stalked.

The chemical contents are protein $11 \%$ flavenoids, steroids, alkaloids, glycosides and lignans. Luteolin indole alkalopid and iridoid glycosides have been isolated from the leaves (Veeranjaneyulu 2010), Another phytochemical content of the plant is phenolics.

Many part of the plant are used for various purposes especially in medical applications. The leaves are considered good for cattle (Bioethics 2010), (crude protein 11.9\%) and are used as feed to Evi-silk worm.

The root and bark of Gmelina arborea are claimed to be stomache, galactagogue, laxative and antihelmintic; improve appetite, useful in hallucination, piles, abdominal pains, burning sensations, fevers, "tridosha" and urinary discharge. Leaf paste is applied to relieve headache and juice is used as wash for ulcers.

Flowers are sweet, cooling, bitter, acid and astringent. They are useful in leprosy and blood diseases. The fruit is acrid, sour, bitter, sweet, cooling, diuretic tonic, alternative astringent to the bowels; promote growth of hairs, useful in anaemia, ulcers, thirst and vaginal discharge. The plant is also used in the treatment of diabetes, piles and fever(Yadesh 2010), wound healing.

\section{Materials And Method}

Fifty six female albino rats were used in that study. They were kept in iron cage at room temperature and left in animal house for 2 weeks to get acclimatized to the environment before commencing an acute feeding which lasted for 28 days.

\section{Experimental Designs}

Fifty six albino rats (140-160g) were selected randomly and divided into three groups(3 groups). Rats in group $\mathrm{C}$ served as those on high dose extract, Group B served as those on low dose extract while those in group A served as control. The test rats received there normal rat feed and water and libitum in addition to oral administration of $5 \mathrm{mg} / \mathrm{ml}$ once daily of the leaf extract of Gmelina arborea. 


\section{Preparation Of Extract}

$200 \mathrm{~g}$ of leaves of Gmelina arborea were selected, washed, dried in the sun and later oven dried, cut and pulverized to fine powder. Hot distilled water, $70-80^{\circ} \mathrm{c}$ was added to $40 \mathrm{~g}$ of the powdered leaves in a round bottomed flask. The suspension was allowed to stand for hours, after which was filtered out thoroughly with cheese cloth. The filtrate was further filtered out through a Whatman's No.1 filter paper. The extract was dried by evaporation giving a percentage yield of $0.5 \mathrm{~g}$. The dried extract was dissolved in $1000 \mathrm{mlof}$ sterile water to give concentration used for the study. The extract was administered by gavage.

\section{Phytochemical Analysis Of Leaves}

The aqueous extract of the leaves was screened for the presence or absence of metabolites using standard phytochemical screening procedures as described by Harbourne (1973), Trease and Evans (1996).

The extract was tested for saponins, alkaloids, flavenoids, calcium, reducing sugars, glycosides, carbohydrates, steroids, acidic compounds, fats and oil.

Toxicity study was done by method of Yadesh 2010. Albino mice were treated with aqueous extract $(300,2000$ and 5000$) \mathrm{mg} / \mathrm{kg}$ orally. The animals were observed periodically during the first $24 \mathrm{~h}$ after administration of the extract; and daily there after for 14 days. In the repeated dose, aqueous extracts of Gmelina arborea was given for $0.5 \mathrm{~g} / \mathrm{kg}$ daily for 28 days by oral means (acute study).

The aqueous extract did not produce mortality in the mice used for toxicity study and in the wistar rats used for acute study.

\section{Determination Of Haematological And Biochemical Indices}

Blood samples collected into EDTA sequestrene bottles were used for the haematological and biochemical studies within hours. The Packed Cell Volume was determined according to the haematocrit method described by Alexander and Griffiths. The haemoglobin concentration was estimated according to the cyanmethaemoglobin method as described by Alexander and Grifiths; white blood cell count, differencials and platelet count were estimated according to the visual method of Dacie and Lewis (1991).

\begin{tabular}{|c|c|c|c|c|c|c|c|c|}
\hline Contents & $\begin{array}{l}\text { Resins, } \\
\text { Tannins, } \\
\text { steroid, } \\
\text { Terpenoids } \\
\end{array}$ & Alkaloids & $\begin{array}{l}\text { Glycosid } \\
\text { es }\end{array}$ & Flavenoids & $\begin{array}{l}\text { Reducing } \\
\text { sugar }\end{array}$ & $\begin{array}{l}\text { Carbo } \\
\text { Hydrate }\end{array}$ & Saponins & Calcium \\
\hline $\begin{array}{l}\text { Degree of } \\
\text { concentrati } \\
\text { on }\end{array}$ & - & ++ & + & ++ & + & +++ & - & ++ \\
\hline
\end{tabular}

The biochemical analysis was carried out as described by Baker (1985).

\section{Statistical Analysis}

The results obtained in the study for $\mathrm{Hb}$ concentration, wbc count, white blood cell differentials, platelet count and liver function test were represented as mean and standard deviation (mean \pm S.D) while students' t-test was used to compare the result of the control and the tests. A P-value of less than $(\mathrm{p}<0.05)$ or equivalent to $(\mathrm{p}=0.05)$ was considered significant.

\section{Results}

The results obtained in the study are shown in the tables 1-4.

Table 1: The phytochemical analysis of Gmelina arborea.

- Negative (absent).

+ Present in small concentration.

++ Present in moderate high concentration.

+++ Present in very high concentration. 
Table 2: Haematological profile of control rats and those gavaged with water extracts of Gmelina arborea for 28 days.

\begin{tabular}{|l|l|l|l|}
\hline Extracts & $\mathrm{Hbg} / \mathrm{dl} \pm$ S.D & PCV $\% \pm$ S.D & Platelets x $10^{6} \pm$ S.D \\
\hline $\begin{array}{l}\text { Group A (control) } \\
\text { Extract free }\end{array}$ & $13.5 \pm 2.5$ & $41 \pm 0.5$ & $160 \pm 42$ \\
\hline $\begin{array}{l}\text { Day l before } \\
\text { G.arboea }\end{array}$ & $13.4 \pm 1.0$ & $41 \pm 0.6$ & $162 \pm 3.0$ \\
\hline $\begin{array}{l}\text { Group B Low Dose } \\
\text { after G.arborea }\end{array}$ & $13.4 \pm 1.6$ & $40 \pm 0.3$ & $162 \pm 28$ \\
\hline $\begin{array}{l}\text { Group C High dose } \\
\text { 28 days after } \\
\text { G.arborea }\end{array}$ & $15.2 \pm 2.5$ & $45.3 \pm 1.6$ & $200 \pm 58$ \\
\hline Level of significance & $\mathrm{P}<0.05$ & $\mathrm{P}<0.05$ & $\mathrm{P}<0.05$ \\
\hline
\end{tabular}

Table 3: Liver Function Tests (Biochemical profile) in Control rats and those gavaged with water extracts of Gmelina arborea for 28 days.

\begin{tabular}{|c|c|c|c|c|c|}
\hline Groups & $\begin{array}{l}\text { Total } \\
\text { bilirubin } \\
\text { mg/dl } \pm \text { S.D }\end{array}$ & $\begin{array}{l}\text { Conj } \\
\text { Bilirubin } \\
\text { mg/dl } \pm \text { S.D }\end{array}$ & $\begin{array}{l}\text { Alk Phos } \\
\text { iu/lı s.D }\end{array}$ & $\begin{array}{l}\text { Asp. } \\
\text { Transaminase } \\
\text { iu/lt S.D }\end{array}$ & $\begin{array}{l}\text { Alanin Trans } \\
\mathrm{iu} / \mathrm{L} \pm \text { S.D }\end{array}$ \\
\hline $\begin{array}{l}\text { Group A }(n=16) \\
\text { Control extract } \\
\text { Free }\end{array}$ & $0.4 \pm 0.1$ & $1.2 \pm 0.6$ & $72 \pm 4.0$ & $9 \pm 3.0$ & $12.0 \pm 5.0$ \\
\hline $\begin{array}{l}1 \text { Day before } \\
\text { extract }\end{array}$ & $0.3 \pm 0.1$ & $1.2 \pm 0.6$ & $70 \pm 8.0$ & $9 \pm 3.0$ & $12.0 \pm 5.0$ \\
\hline $\begin{array}{l}\text { Group B }(n=20) \\
\text { Low Dose of } G \text {. } \\
\text { arboea }\end{array}$ & $0.4 \pm 0.1$ & $1.1 \pm 0.5$ & $73 \pm 6.0$ & $10.4 \pm 2.0$ & $11.0 \pm 6.0$ \\
\hline $\begin{array}{l}\text { Group C }(n=20) \\
\text { High dose of } G \text {. } \\
\text { arborea }\end{array}$ & $0.4 \pm 0.1$ & $1.2 \pm 0.5$ & $72 \pm 4.0$ & $10.4 \pm 2.0$ & $12.4 \pm 5.0$ \\
\hline Significance & $p>0.05$ & $\mathrm{P}>0.05$ & $p>0.05$ & $p>0.05$ & $p>0.05$ \\
\hline
\end{tabular}

Table 4: White blood cell counts and differentials of control rats and those gavaged with water extract of Gmelina arborea for 28 days.

\begin{tabular}{|l|l|l|l|l|l|l|}
\hline Groups & $\begin{array}{l}\text { WBC per } \\
\mathrm{mm}^{3} \pm \text { S.D }\end{array}$ & $\mathrm{N} \% \pm$ S.D & $\mathrm{L} \% \pm$ S.D & $\mathrm{E} \%$ S.D & $\mathrm{M} \% \pm$ S.D & $\mathrm{B} \%$ \\
\hline $\begin{array}{l}\text { Group A (n=16) } \\
\begin{array}{l}\text { Control Extract } \\
\text { free }\end{array}\end{array}$ & $4,850 \pm 125$ & $45 \pm 0.6$ & $52 \pm 4$ & $1 \pm 1$ & $2 \pm 1$ & $0 \pm 0$ \\
\hline $\begin{array}{l}\text { Day 1 before } \\
\text { G.arborea }\end{array}$ & $4,800 \pm 120$ & $48 \pm 11.0$ & $49 \pm 9.0$ & $1 \pm 1$ & $2 \pm 1$ & $0 \pm 0$ \\
\hline $\begin{array}{l}\text { Group B (n=20) } \\
\text { Low dose 28 days } \\
\text { after extract }\end{array}$ & $4,820 \pm 100$ & $47 \pm 8$ & $52 \pm 6$ & $0 \pm 1$ & $1 \pm 1$ & $0 \pm 0$ \\
\hline $\begin{array}{l}\text { Group C ( }=20) \\
\begin{array}{l}\text { High Dose 28 } \\
\text { days after extract }\end{array}\end{array}$ & $4,700 \pm 95$ & $47 \pm 4.0$ & $50 \pm 7.0$ & $2 \pm 1$ & $1 \pm 0$ & $0 \pm 0$ \\
\hline Significance & $\mathrm{p}>0.05$ & $\mathrm{P}>0.05$ & $\mathrm{p}>0.05$ & $\mathrm{p}>0.05$ & $\mathrm{p}>0.05$ & $\mathrm{p}>0.05$ \\
\hline
\end{tabular}

\section{Discussion}

Herbaceous plants have been found useful in the treatment and management of various ailments and their protective effect on the body from damage due to free radicals and lipid per oxidation has been reported (Wikipedia, 2010). The effects of aqueous leaf extract of Gmelina arborea on the haematological and biochemical profile of albino rats have been studied. Though the plant has been found useful in the treatment of snake bites, fever, piles and diabetes, however, there is little toxicological information available regarding its safety after exposure (Yadesh, 2010).

Toxicity also may affect the result of this study in rats and so acute toxicity studies using $\operatorname{LD}_{50}$ were carried out before the extract was administered to the animals. The result of the lethality studies shows that the $\mathrm{LD}_{50}$ in rats using extract of Gmelina arborea was $500 \mathrm{mg} / \mathrm{dl}$ and the doses used in the study $(5 \mathrm{mg} / \mathrm{kg})$ was therefore far below the lethal dose and so was considered safe to the animals used throughout the period of study. 
The extract of Gmelina arborea increased the haemoglobin concentration and Packed cell volume of rats after twenty-eight $(28)$ days of feeding $(\mathrm{P}<0.05)$. This is consistent with the fact that Gmelina arborea is rich in carbohydrate and calcium (table 1), hence its significance in haemopoiesis.

The white blood cells were also increased in rats fed with the extract of G. arborea. This could also be linked to their carbohydrate (sugar) content (Iwu, 1983). The increase in leukocyte count could be physiologically as suggested by Pennington (1978).

Calcium being moderately present in the extract of G. arborea (Table 1) may point to active role of the extract in clotting of blood. It was observed that calcium was a principal active ingredient present in the plasma and bone. It is free calcium ions that are physiologically active in coagulation mechanism (Ureme 1996).

Calcium ions are essential for the conversion of prothrombin to thrombin and for the normal action of heart muscles and for neuromuscular conduction.

Biochemical analysis showed no marked differences in any of the parameters examined in either the control or treated groups thus indicating the safe use of the plant in the body.

It was shown from the phytochemical studies that there were presence of typical plant constituents such as calcium, carbohydrate, reducing sugar, flavenoids and glycosides while other constituents such as resins, steroids, tannins, terpenoids and saponins were absent (Table 1).

For this reason of non toxicity in the animal system, it could be helpful to the human system, Gmelina arborea can be planted in garden and avenues. It is also good for cattle and used as a feed to eri-silkworm. The root and bark are claimed to be stomachie, galactagogue, laxative, improve appetite, useful in hallucination, piles, abdominal pains, burning sensations. Leaf paste is applied to relive headache and juice is used as wash for ulcers (Wikipedia, 2009).

\section{References}

[1]. ALEXANDAR R.R and GRIFITHS J.M (1993). Haematocrit in: Basic Biochemical methods $2^{\text {nd }}$ Ed. John Willey and Sons. Inc. Publications New York pp 186-187.

[2]. Available from http://bioethics od.nih gov/animals html (Last accessed on 2010 Dec 30).

[3]. BARKER F.J (1985). Liver Function tests Introduction to Medical laboratory Technology. Butterworths Publications Woburn London $\mathrm{p}$ 134-139.

[4]. DACIE J.K and LEWIS S.M (1991). Practical Haematological in: Biochemical methods $2^{\text {nd }}$ Ed. John Willey and Sons. Inc. Publications New York pp 186-187.

[5]. IWU M, (1983). I.A.P University of Nigeria Nsukka Project Report. Traditional Igbo Medicine, 30.

[6]. JENSEN M, (1995). Trees commonly cultivated in South East Asia; illustrated field guide. Publication: 1995/38, FAO, Bangkok, Thailand.

[7]. KIRTIKAR K.R, BASU B.D (1999). Indian Medicinal Plants. Dehradun; International Book Distributor, p1932-3.

[8]. PENNIGTON D (1978). Pathological Variation in White Cell Count Values. Clinical Haematology in Medical practice. Blackwell Scientific Publication Osney Mend Oxford 0X20EI. 8 Johnson Street London Pp 396.

[9]. UREME A (1996). The relationship of clot retraction platelet count and serum calcium concentration in apparently healthy adolescent in Enugu. Journal of Environmental Health Vol 6. Pp 22.

[10]. Veeranjanevulu a (2010). "Evaluation of acute and reported dose toxicity of the methanol extract (ME) of the Gmelina arborea stem bark/. School of Pharmacy and Technology Management SVKM's NMIMS University, V.L. Mehta Read, Vile Parle (W), Mumbai $=400056$ Maharashtra India.

[11]. WIKIPEDIA 2009. "A tree specie references and election guide: http//www.worldagroforestrycentreorg/seaproducts/AFD bases/AF/asp/specie Info asp ${ }^{2}$ SpID-9.

[12]. Yadesh Kulkami, Addepalli Veeranjanevulu, (2010). Toxological studies on aqueous extract of Gmelina arborea in rodents Dec 2010 Vol. 48 No 12 pg 1413-1420. 